\title{
The Role of the Microbial Community in Mineral Formation in the Thermal Springs of the Baikal Region
}

\author{
Valentina G. Budagaeva* and Darima D. Barkhutova \\ Institute of General and Experimental Biology SB RAS \\ 6 Sakhyanova, Ulan-Ude, 670047, Russia
}

\begin{abstract}
Received 04.10.2018, received in revised form 07.11.2018, accepted 10.12.2018
Alkaline nitrogen thermal springs characterised by high temperatures and $\mathrm{pH}$ values are extreme habitats in the Baikal area. Microbial mats are prokaryotic communities consisting of photosynthetic cyanobacteria and a range of other aerobic and anaerobic microorganisms. X-ray diffractometry (XRD) and scanning electron microscopy (SEM) were used to study the composition of minerals formed in microbial communities in the outflows of the Baikal thermal springs. Among the minerals, calcite, quartz and opal were identified. Deposits of iron sulphide (pyrite framboids), a product of the metabolic activity of microorganisms, were found in hydrogen sulphide springs. The calcite crystals had an ellipsoidal, faceted cubic or prismatic shape. Silica (opal) was deposited as a dense crust with silicified filaments of cyanobacteria; siliceous formations of biogenic origin represented by siliceous covers on the filaments of cyanobacteria and diatom frustules were observed. Microbial fouling and mats serve as reaction surfaces for the nucleation of heterogeneous silica particles in the process of amorphous silica and opal formation. Calcite is formed as a result of the metabolic activity of organisms due to the appearance of local zones with high $\mathrm{pH}$ values and the formation of a glycocalyx (exopolysaccharides), which absorbs calcium ions. Pyrite framboids grow on the surfaces of fragments of diatom shells, and deposits of individual crystallites are also observed in the thickness or on the surface of microbial mats.
\end{abstract}

Keywords: thermal springs, microbial mat, mineral formation, microbial-induced mineralization, diffractogram, silicon dioxide, silica, calcite, aluminosilicates, framboid pyrite.

Citation: Budagaeva V.G., Barkhutova D.D. The role of the microbial community in mineral formation in the thermal springs of the Baikal region. J. Sib. Fed. Univ. Biol., 2018, 11(4), 340-355. DOI: 10.17516/1997-1389-0077.

(C) Siberian Federal University. All rights reserved

This work is licensed under a Creative Commons Attribution-NonCommercial 4.0 International License (CC BY-NC 4.0).

* Corresponding author E-mail address: valmpa@mail.ru 


\title{
Роль микробного сообщества в минералообразовании в термальных источниках Прибайкалья
}

\author{
В.Г. Будагаева, Д.Д. Бархутова \\ Институт общей и экспериментальной биологии СО РАН \\ Россия, 670047, Улан-Удэ, ул. Сахъяновой, 6
}

Щелочные азотные гидротермы, характеризуюшиеся высокими значениями температуры и рН, являются экстремальными местообитаниями на территории Прибайкалья. Микробнье маты представляют собой прокариотные сообщества, состоящие из фотосинтезирующих цุианобактерий, а также различных аэробных и анаэробных микроорганизмов. С помощьью рентгенофазового анализа (РФА) и сканирующей электронной микроскопии (СЭМ) определень минераль в микробных сообществах на выходах термальных источников Прибайкалья. Среди минералов выявлены кальц̧ит, квари и опал. В сероводородных источниках обнаруженьл отложения сульфида железа (фрамбоиды пирита), образовавшиеся в результате метаболической деятельности микроорганизмов. Кристалль кальцита имели эллипсоидальную форму, ограненную кубическую или призматическую. Кремнезем (опал) отлагался плотной коркой с окремнением нитей цианобактерий, выявлены кремнистые образования биогенного происхождения - кремнистье чехль на нитях ичинобактерий и створки диатомовых водорослей. Микробные обрастания и маты выступают в качестве реакционных поверхностей для нуклеации гетерогенных кремниевых частии при образовании аморфного кремнезема и опала. Кальцит формируется в результате метаболической активности организмов за счет образования локальных зон с высоким рН и образования гликокаликса (экзополисахаридов), поглощзающего ионы кальциия. Фрамбоиды пирита «растут» на поверхности обломков панизирей диатомовых водорослей, также встречены россыпи отдельных кристаллитов в толще микробного мата или на поверхности.

Ключевые слова: термальные источники, микробный мат, минералообразование, микробноиндуциированная минерализация, дифрактограмма, диоксид кремния, кремнезем, кальциит, алюмосиликаты, фрамбоидальный пирит.

\section{Introduction}

Microbial mats are considered to be the earliest ecosystems (Tice, Lowe, 2004; Noffke et al., 2006). They are characterised by high metabolic rates and the fast circulation of macroelements at a very small $(\mathrm{mm}-\mu \mathrm{m})$ scale (Dupraz et al., 2009). Due to the high sustainability of these ecosystems, microbial mats are used as model systems in studies of microbial and biogeochemical interactions (cycles of carbon, nitrogen and sulphur) as well as microorganismmineral interactions (precipitation/dissolving of carbonates, silicates and oxides) (Dupraz, Visscher, 2005). Microbial communities, particularly microbial mats, have a unique ability to alter the balance between more reduced and more oxidised forms of carbon (organic matter and $\mathrm{CO}_{2}$ ) (Tice, Lowe, 2004).

Cyanobacterial silicification is an important geological process in modern geothermal habitats 
that might influence microbial fossilisation and the formation of sedimentary rocks in hot springs (Konhauser et al., 2001; Orange et al., 2013).

The process of microbial silicification has been repeatedly observed in hot springs with high concentrations of silicic acid solutions in various regions of the world, including Kamchatka, Kenia, New Zealand, and Yellowstone National Park (USA) (Phoenix et al., 2000; Konhauser et al., 2001; Yee et al., 2003).

Silica is present in organisms in the form of the minerals opal, quartz, and cristobalite. Silicate structures with precisely-controlled morphologies are produced in large amounts by unicellular organisms, such as diatoms (Perry, Keeling-Tucker, 2000). The most common minerals in living organisms are silicon oxides, including their hydrated forms (opal), calcium carbonates (vaterite, aragonite, and calcite), iron oxides and hydroxides (including magnetite), and different forms of apatite (Skinner, 2005). Currently, solid evidence that microorganisms, especially archaea and bacteria, play a large role in geological processes has been accumulated (Namsaraev et al., 2011).

Biomineralisation is the process of creating biocomponents by microorganisms. Biologically induced mineralisation is the precipitation of minerals, which usually occurs extracellularly, due to a change in physicochemical conditions caused by bacterial metabolic activity. Microbially induced mineralisation, a type of biologically induced mineralisation, is entirely the result of microbial metabolism (Franke, Bazylinski, 2003; Weiner, Dove, 2003). For instance, in the microbially induced calcite $\left(\mathrm{CaCO}_{3}\right)$ precipitation, some organisms can excrete one or more metabolic products $\left(\mathrm{CO}_{3}{ }^{2-}\right)$ reacting with $\left(\mathrm{Ca}^{2+}\right)$ ions in the environment followed by mineral precipitation. Thus, bacteria can cause $\mathrm{CaCO}_{3}$ to precipitate extracellularly in reactions related to the metabolic pathways of photosynthesis (McConnaughey, Whelan, 1997), ammonification, denitrification, sulphide reduction (Hammes et al., 2003), anaerobic sulphide oxidation and urea decomposition by destructor bacteria (Chen et al., 2009; Wen et al., 2004).

Calcium carbonate precipitation via urea hydrolysis is the most common method of microbially induced calcite precipitation (DeJong et al., 2010; De Muynck et al., 2010). During this process, bacteria use urea as a nitrogen and energy source and hydrolyse it, producing ammonia and some byproducts consisting of carbonates and bicarbonates. This process increases the solution alkalinity, which creates favourable conditions for calcium carbonate precipitation (Chou et al., 2011).

In nature, calcium carbonate exists in three crystal polymorphic forms: calcite, aragonite and vaterite. Calcite is the most common and stable polymorphic form of calcium carbonate that precipitates in bacterial communities (Rodriguez-Navarro et al., 2012). The calcite form is determined by both environmental conditions and the species of microorganisms in the community. Diverse bacterial species provide for the precipitation of different types of calcium carbonate forming mostly spherical or polyhedral crystals (Canaveras et al., 2001). In addition to cyanobacteria, some genera of bacteria, namely, sulphate-reducing microorganisms (Warthmann et al., 2000), Myxococcus (Rodriguez-Navarro et al., 2012), Halobacteria, and Pseudomonas (Jha et al., 2009), have been described as being involved in the formation of carbonate minerals.

Biologically controlled mineralisation is a completely different process in which minerals are formed intracellularly, and cells are completely in control of each step: nucleation, growth, morphology and placement of minerals. Thus, exo- and endoskeletons of animals (Mollusca, 
Echinodermata, Mammalia) are formed (Weiner, Dove, 2003).

In biologically induced mineralisation, external factors of the environment (physical and chemical), but not microbial activities, are responsible for the creation of conditions (e.g., high alkalinity) needed for mineral precipitation. However, the organic matrix takes part in biologically induced precipitation and influences the morphology and content of the crystals due to the interaction between the emerging mineral and the organic matter, which serves as a matrix for precipitation.

The ability of bacteria to synthesize their own geological and biological substrates with microbially induced mineralisation and the utilisation of metabolites enables such systems to adapt to a wide range of ecological conditions that have changed over the course of Earth's history.

The main objective of the research was to study the minerals in microbial mats from thermal springs of the Baikal area by X-ray diffractometry (XRD) and scanning electron microscopy (SEM).

\section{Materials and methods}

The study sites were the Alla, Garga, Seyuyskiy, Umhei and Kuchiger thermal springs located in the Kurumkanskiy and Barguzinskiy Districts in the Republic of Buryatiya.

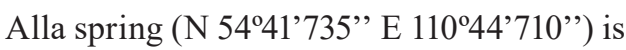
located in the Kurumkanskiy District at $706 \mathrm{~m}$ above sea level at the foot of the Barguzinskiy ridge in the valley of the River Alla, where it exits the mountains.

Garga thermal spring (N 5419'203" E $\left.110^{\circ} 59^{\prime} 646^{\prime \prime}\right)$ is located in the valley of the River Garga, where it exits the Ikat mountain ridge.

Umhei thermal spring (N 54'59'253” E $\left.111^{\circ} 07^{\prime} 152^{\prime \prime}\right)$ is located in the northern part of the Barguzin depression, $100 \mathrm{~km}$ from the district centre. The spring issues on an island with an area of approximately 8 ha formed by the Barguzin River at the junction of two mountain ridges, the Barguzinskiy and the Ikat.

Kuchiger spring (N 54 52'934” E $\left.111^{\circ} 00^{\prime} 050^{\prime \prime}\right)$ is located in the Kurumkanskiy District at $570 \mathrm{~m}$ above sea level on the northwestern side of the Barguzinskiy ridge.

The thermal spring Seyuyskiy (N 5450'142'” E 111'18'099") is located at $572 \mathrm{~m}$ above sea level in the Kurumkanskiy District, $80 \mathrm{~km}$ from the village of Krumkan, in the mouth of the Jirga River on the right bank of the Seyuya River.

Samples of water and microbial mats for the study were collected in the summer and autumn period from 2013 to 2015. Samples were placed in sterile glassware. To study the deposition of minerals, microbial mats were packed in order to preserve the mat structure. Later, under laboratory conditions, mats were separated into layers, dried at room temperature and stored at $+4^{\circ} \mathrm{C}$.

The temperature, $\mathrm{pH}$, oxidation-reduction potential (Eh), and TDS (total amount of dissolved substances) were measured at the sampling points. The temperature was measured with a Prima sensor electrothermometer (Portugal), and $\mathrm{pH}$ and Eh were measured using a portable $\mathrm{pH} /$ ORP meter (HANNA, Romania). The total amount of dissolved substances was determined using a TDS-Meter Hi96301 (HANNA, Bangladesh). The study of the minerals in the microbial mats was carried out using a Hitachi TM 1000 scanning electron microscope (Japan) with an X-ray spectral analyser SwiftED-TM EDX. Dried samples were thoroughly ground in agate mortars. Samples of approximately $1 \mathrm{~g}$ were placed in a cuvette, and the diffractograms were taken. The mineral composition of the samples was determined by X-ray diffraction analysis on a diffractometer D-8 Advance from BRUKER AXS $\left(\mathrm{CuK}_{\alpha}\right.$-radiation, graphite monochromator). The reflection intensities were estimated by the height of the peaks in the diffractograms. The silicon 
content was determined spectrophotometrically. The method is based on the reaction of the formation of the yellow molybdenum complex, its reduction and measurement of the optical density of the blue reduced silica-molybdenum complex. The optical density was measured with a CECIL-1021 spectrophotometer (UK).

\section{Results}

Low-mineralised $\left(140-1000 \mathrm{mg} / \mathrm{dm}^{3}\right)$ thermal waters $\left(38-74{ }^{\circ} \mathrm{C}\right)$ are common in the Baikal area. The water of these springs is alkaline, with a sulphate sodium or sulphate-hydrocarbonate sodium composition (Borisenko, Zamana, 1978). The $\mathrm{pH}$ varied from 9.0 to 10.0 . High values $(\mathrm{pH}$ 9.9-10.0) were observed in the water of Seyuya and Kuchiger springs. An average alkaline reaction ( $\mathrm{pH}$ 9.0-9.5) was seen in Alla, Umhei and Garga springs. The water temperature at the outflows of the hot springs varied widely. The maximum temperatures $\left(65-73^{\circ} \mathrm{C}\right)$ were recorded in the water of Alla and Garga springs. The water temperatures of Seyuy, Umhei, and Kuchiger thermal springs reached $53^{\circ} \mathrm{C}, 49^{\circ} \mathrm{C}$ and $38^{\circ} \mathrm{C}$, respectively. The oxidation-reduction potential values varied from -380 to $+55 \mathrm{mV}$. Oxidised conditions were observed in the waters of Garga thermal spring. The other hydrothermal springs were characterised by the reduced conditions of hydrothermal waters, which are favourable for anaerobic microbial communities.

In the outflow area and warm streams of the thermal springs, microbial mats of different types developed: cyanobacterial with a predominance of cyanobacteria, cyanobacterial in association with eubacteria, and sulphuric mats. Mat-forming species of cyanobacteria in the examined thermal springs were from the Gloeocapsa, Leptolyngbia, Phormidium and Synechococcus genera. In the thermal spring of Alla, we additionally discovered Microcystis species, in Umhei thermal spring, Oscillatoria, Spirulina and Synechocystis were observed, and in Garga thermal spring, Anabaena were found (Namsaraev et al., 2006; Shargaeva et al., 2013).

The primary destruction of organic matter occurs with the participation of hydrolytic aerobic and anaerobic bacteria; the abundance of these bacteria reached $10-10^{5}$ cells $/ \mathrm{ml}$. Aerobic and anaerobic proteolytic, cellulolytic and saprophyte bacteria were observed in all the examined samples. The maximum counts for aerobic proteolytic bacteria and anaerobic bacteria were $10^{5}$ cells $/ \mathrm{ml}$ and $10^{3}$ cells $/ \mathrm{ml}$, respectively. The counts for anaerobic cellulolytic bacteria reached $10^{2}-10^{3}$ cells $/ \mathrm{ml}$, and the counts reached $10-10^{2}$ for aerobic bacteria (Namsaraev et al., 2011). The terminal processes of the decomposition of organic matter are performed by secondary anaerobes. These include sulphate-reducing bacteria (SRB), which carry out the dissimilative reduction of sulphates to hydrogen sulphide. The abundance of SRB in the examined springs reached a maximum value of $10^{6}-10^{7}$ cells $/ \mathrm{ml}$ of silt when lactate was used as a source of carbon. High numbers of CRP growing both on lactate and on acetate $\left(10^{7}\right.$ cells $\left./ \mathrm{ml}\right)$ were detected in the bottom sediments of Kuchiger thermal springs. The number of sulphate-reducers growing on lactate was higher than the number growing on acetate in the thermal springs of Seyuya and Alla (Kalashnikov et al., 2010).

Minerals precipitating in hot springs were studied with X-ray phase analysis and scanning electron microscopy.

Based on the results of X-ray phase analysis (XRD), carbonate minerals (calcite and aragonite) and silicate minerals (cristobalite and quartz) were found in the microbial mats of the springs.

Calcite deposition was detected in the microbial communities of the springs of Alla and Garga.

The analysis of the diffractograms showed that calcite (syn $\mathrm{CaCO}_{3}$ ) and beta calcite $\mathrm{CaCO}_{3}$ 
precipitated in the microbial community of Alla thermal spring (Fig. 1). Crystals of calcite were either well-faceted (cubic or prismatic) or ellipsoidal (Fig. 2).

Deposits of calcite and silica (opal) were identified in the microbial mat of Garga spring (Fig. 3). The calcite crystals had an oval shape with cyanobacterial filament impressions. Silica (opal) was deposited as a dense crust with silicified filaments of cyanobacteria (Fig. 4).

A distinctive feature of nitrogen hot springs is the presence of silicic acid. In the examined thermal springs, the total amount of silicon reached $120 \mathrm{mg} / \mathrm{L}$ (Alla). Lower silicon concentrations were recorded in Garga (69 mg/L) and Seyuya $(64 \mathrm{mg} / \mathrm{L})$ thermal springs, while the silicon content of the Umhei water was $86 \mathrm{mg} / \mathrm{L}$. The microbial mats of the examined thermal springs contained siliceous formations of biogenic origin in the form of siliceous covers on cyanobacteria filaments and the valves of diatom algae (Fig. 5).
Deposition of silica was observed in the microbial mats of the springs of Garga, Seyuya and Umhei. Silicification of cyanobacterial capsules occurred in those springs, forming dense continuous layers of silica (geyserite) (Fig. 6). Thus, according to XRD data, in Umhei and Seyuya hydrothermal springs, which outflow in the northern part of the Barguzin depression and form a lake, silicon dioxide precipitated in different modifications: quartz, $\beta$-quartz, and cristobalite $\left(\mathrm{SiO}_{2}\right)$ (Fig. 7).

The formation of iron sulphide was observed in the microbial communities of the hydrogen sulphide springs Umhei and Kuchiger (Fig. 8). The study of sulphate-reducing bacteria in the springs of the Baikal region showed that these bacteria are common there. Their abundance reached $10^{4}$ cells/ml (Namsaraev et al., 2011). The activity of sulphate-reducing bacteria is closely related to the redox characteristics of the environment, the presence of readily-decomposable organic substances and the influx of significant amounts

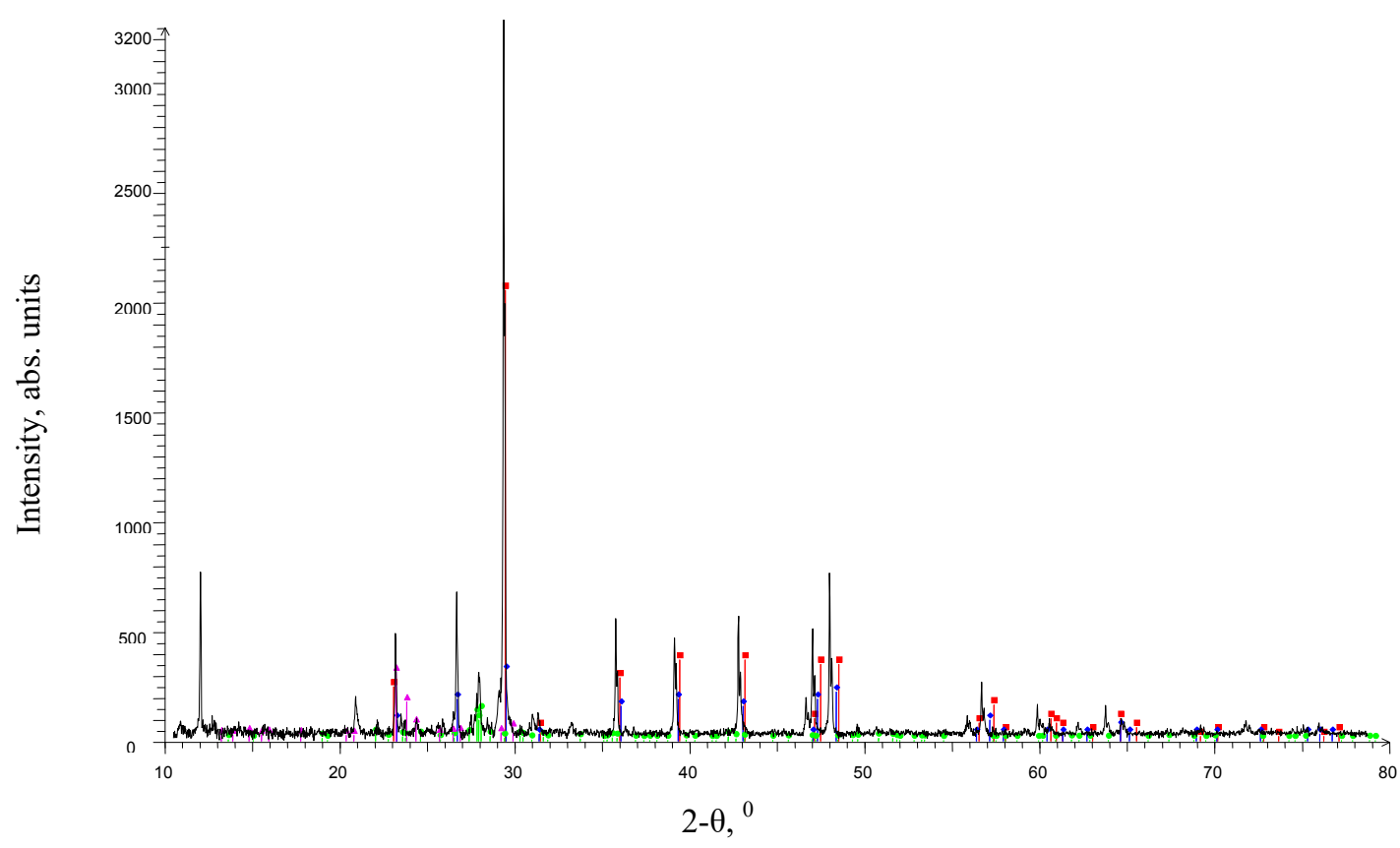

- Calcite, syn $-\mathrm{CaCO}_{3}$; Anorthite - ordered $-\mathrm{CaAl}_{2} \mathrm{Si}_{2} \mathrm{O}_{8} ;$ Calcite - beta-CaCO${ }_{3}$; $\Delta$ Sodium Aluminium Silicate - Na1.82A12Si57O107.91

Fig. 1. Diffractogram of a microbial mat sample from Alla spring 
a

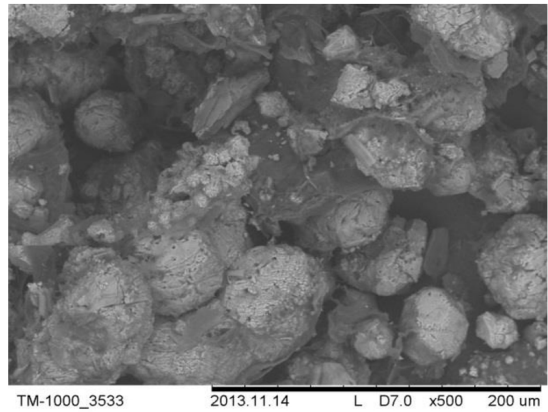

$\mathrm{c}$

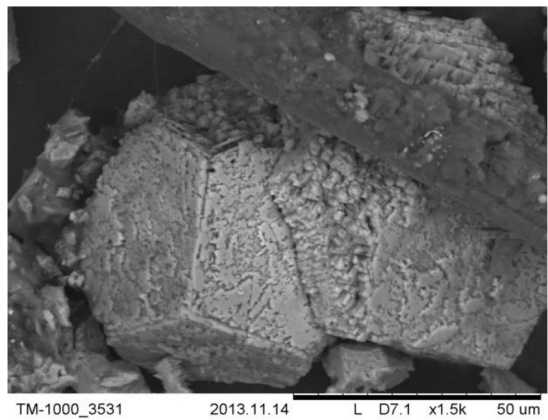

b

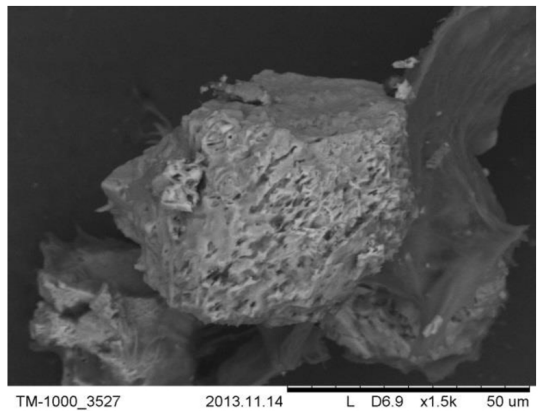

d

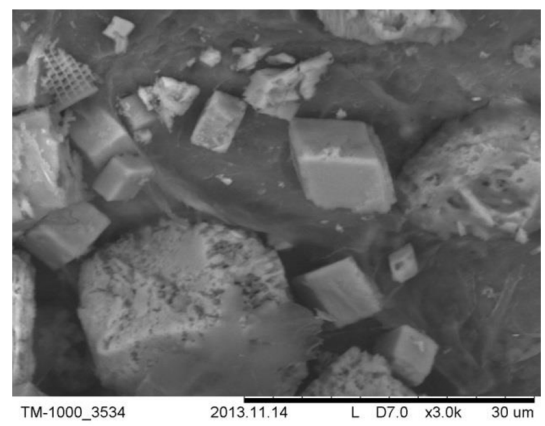

Fig. 2. Calcite minerals formed in the microbial mat of Alla spring: Photo: scanning microscope, scale bars $=30$ $200 \mu \mathrm{m}$

$\mathrm{a}$ - ellipsoidal crystals of calcite; $\mathrm{b}$ - minerals of irregular shape; $\mathrm{c}, \mathrm{d}$ - faceted crystals

a
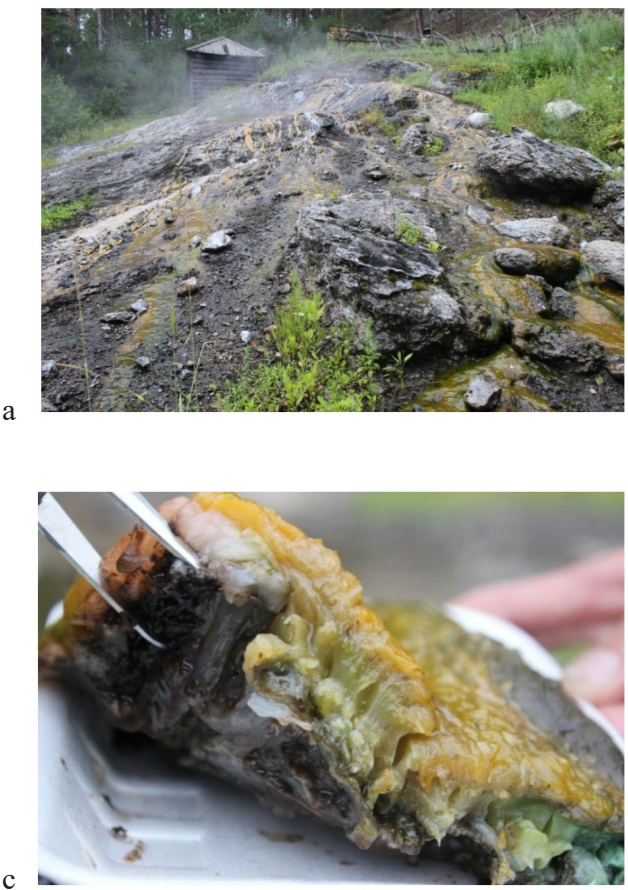

b
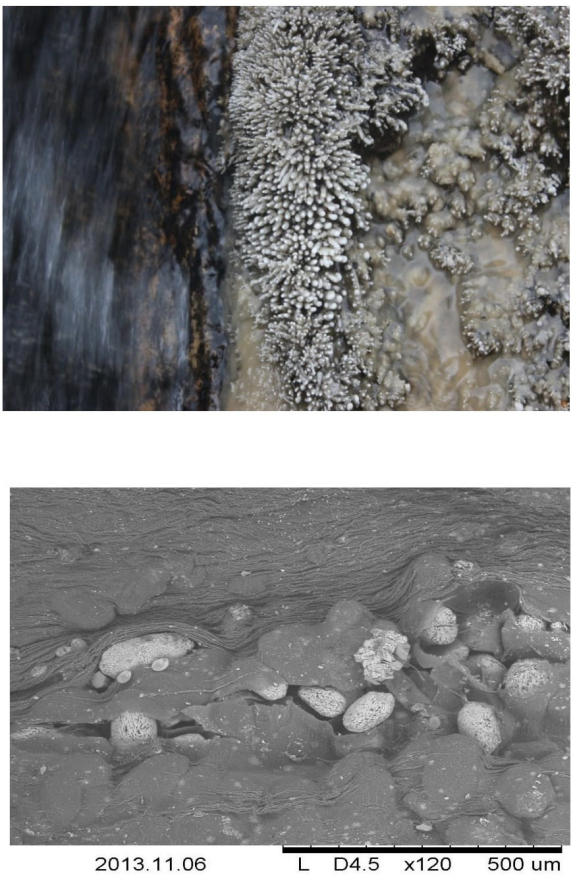

Fig. 3. Thermal spring Garga: Photo: scanning microscope, scale bar $=500 \mu \mathrm{m}$

$\mathrm{a}$ - general view; $\mathrm{b}$ - minerals formed in a microbial mat; $\mathrm{c}$ - sample of a microbial mat; $\mathrm{d}$ - calcite grains entangled with cyanobacterial filaments 
a

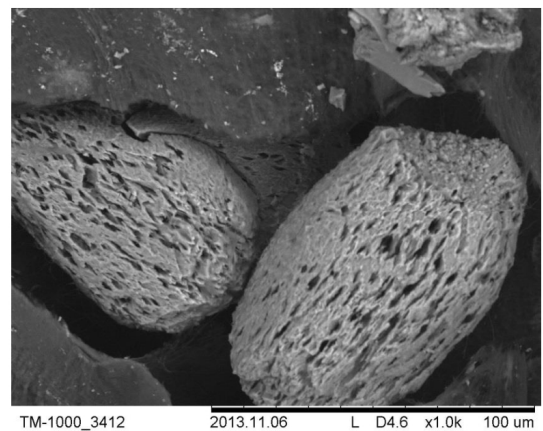

b

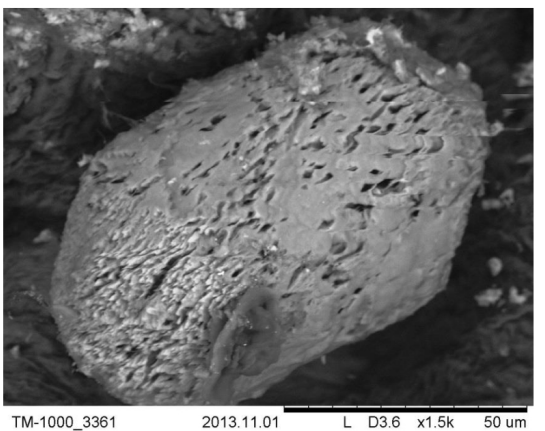

c

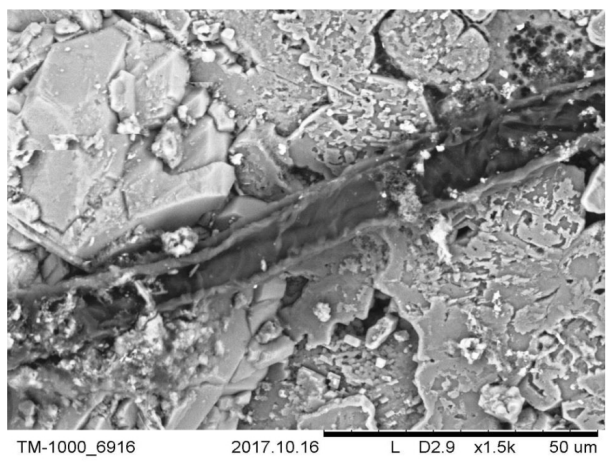

Fig. 4. Deposits of calcite and opal in the cyanobacterial mat of Garga spring: Photo: scanning microscope, scale bars $=50-100 \mu \mathrm{m}$

$\mathrm{a}, \mathrm{b}$ - calcite grains with slots from cyanobacterial filaments; $\mathrm{c}$ - dense layer of opal

a

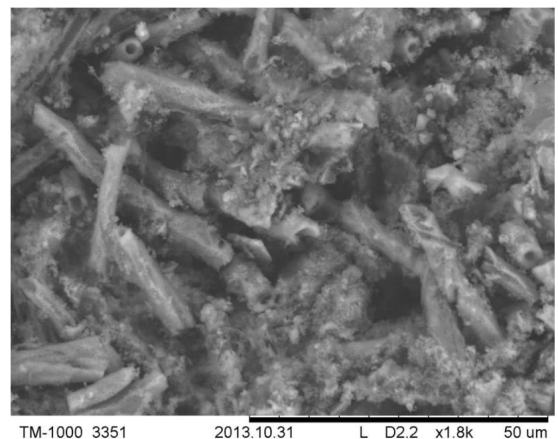

$\mathrm{b}$

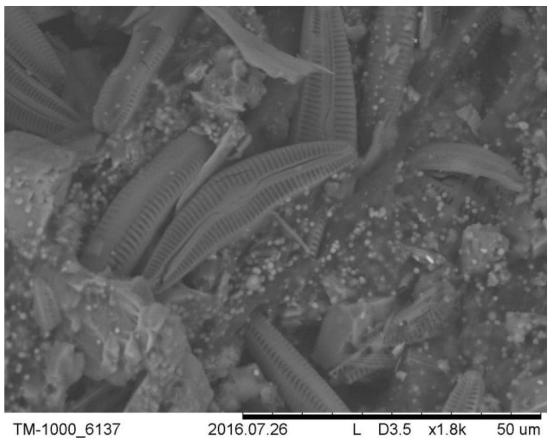

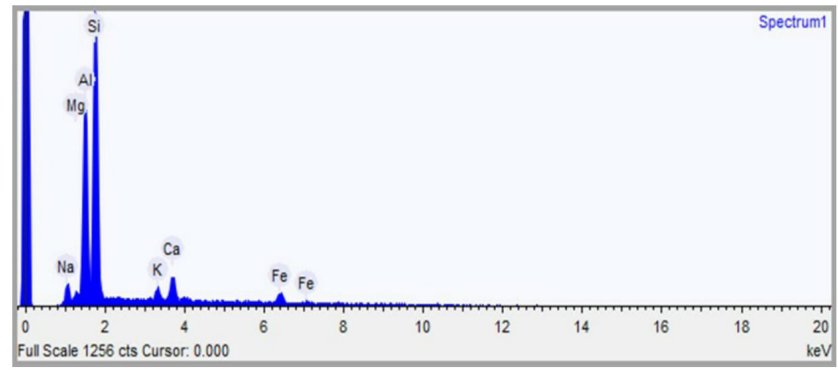

c

Fig. 5. Minerals formed in a cyanobacterial mat: Photo: scanning microscope, scale bar $=50 \mu \mathrm{m}$ a - Seyuya: amorphous silica in a mat; b - Umhei: diatom frustules; $\mathrm{c}$ - chemical composition 


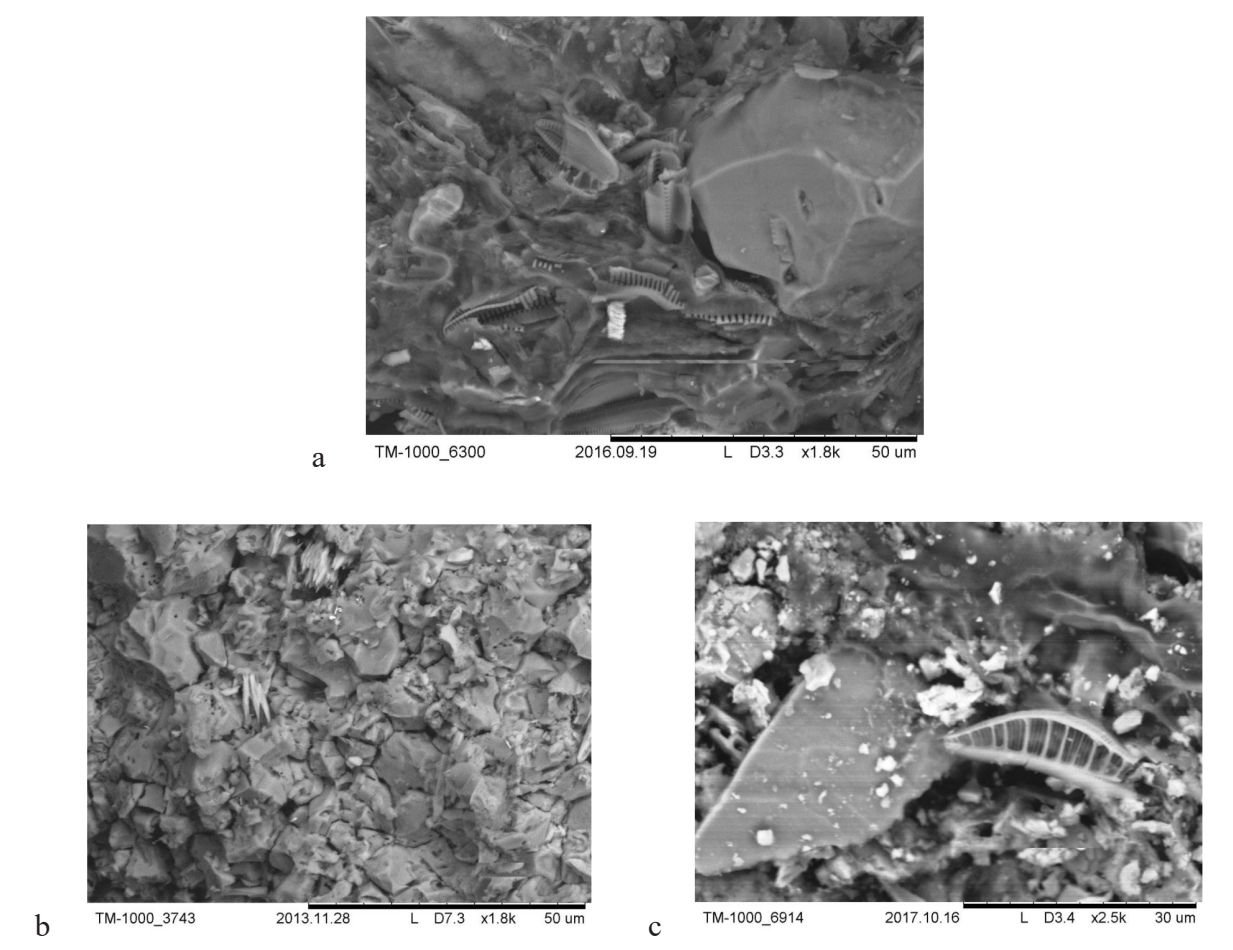

Fig. 6. Silicification in a cyanobacterial mat from the examined springs: Photo: scanning microscope, scale bars $=30-50 \mu \mathrm{m}$

a - Umhei; b - Seyuya; c - Garga

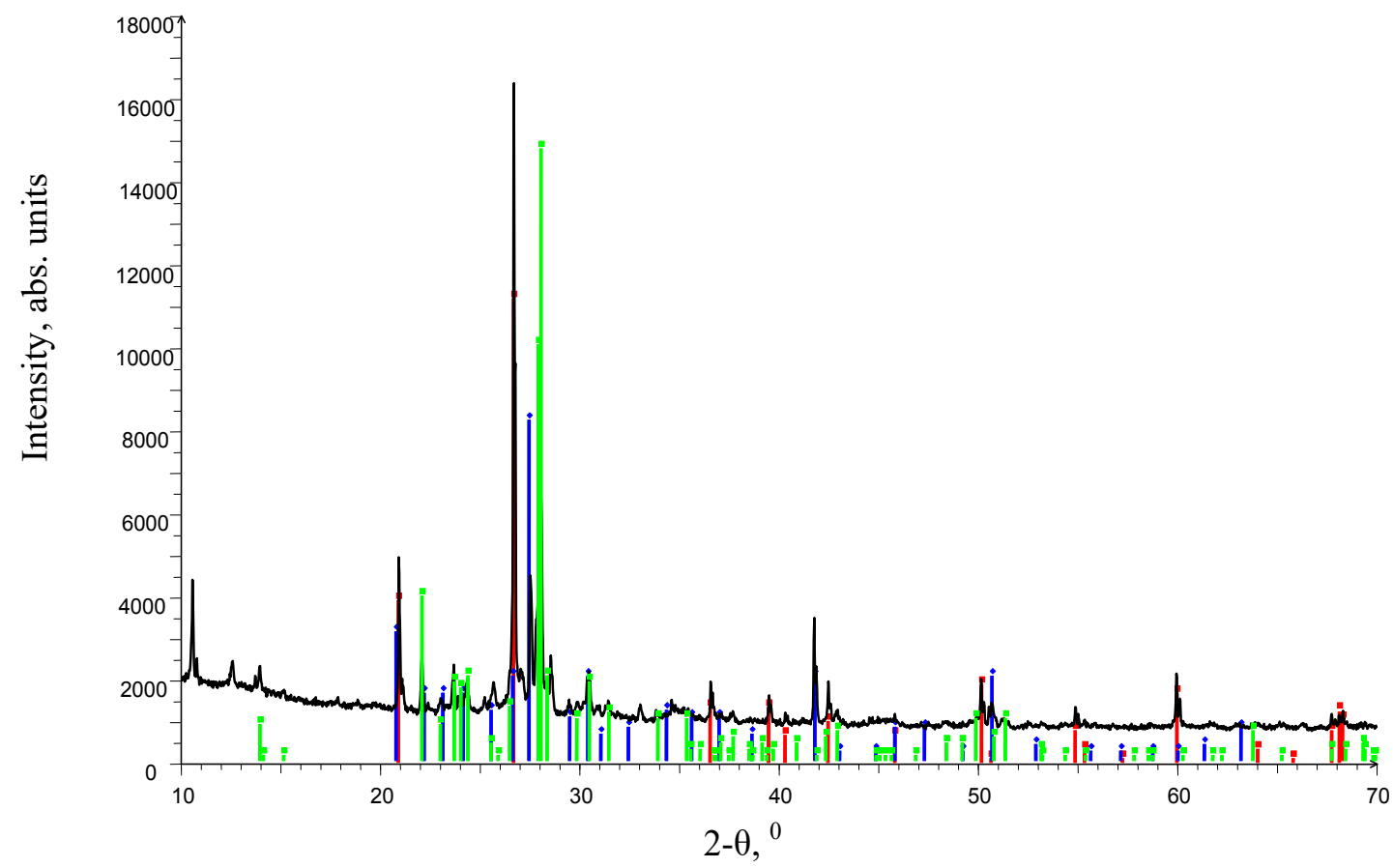

- Albite, calcian, ordered $-(\mathrm{Na}, \mathrm{Ca}) \mathrm{Al}(\mathrm{Si}, \mathrm{Al})_{3} \mathrm{O}_{8} ;$ alpha- $\mathrm{SiO}_{2}-$ Quartz; $\bullet \mathrm{KAlSi}_{3} \mathrm{O}_{8}-$ Microcline

Fig. 7. Diffractogram of an Umhei microbial mat 

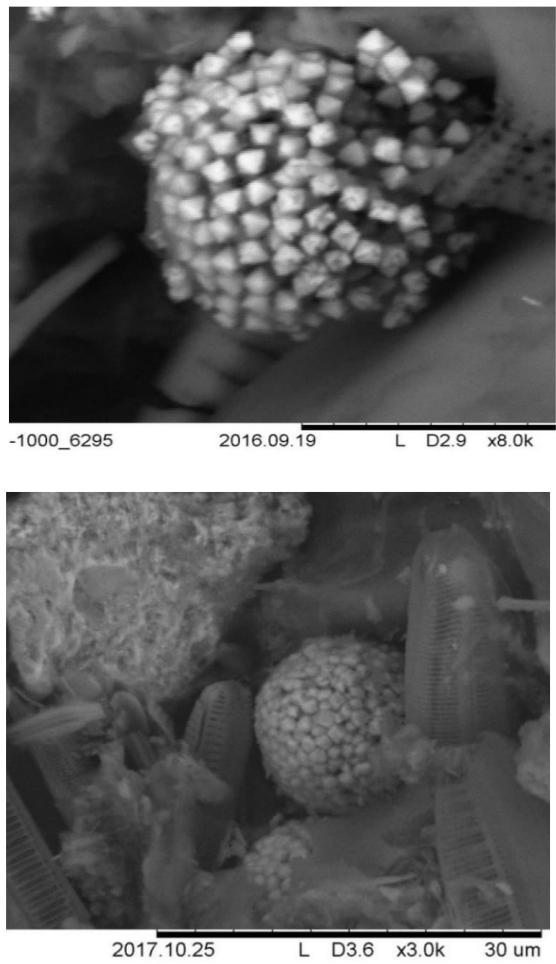

$\mathrm{b}$

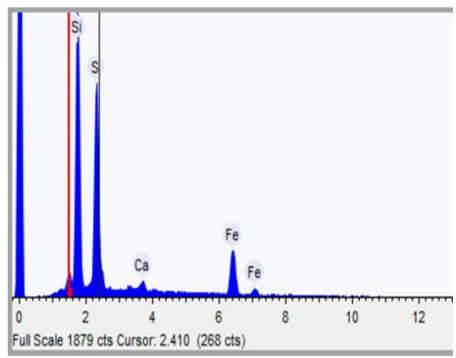

d

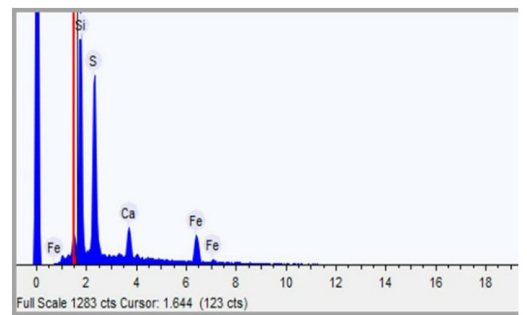

Fig. 8. Pyrite framboid deposits: Photo: scanning microscope, (a) scale bar $=10 \mu \mathrm{m}$; (b) scale bar $=30 \mu \mathrm{m}$ $\mathrm{a}$ - Kuchiger microbial mat; $\mathrm{b}$ - chemical composition; $\mathrm{c}$ - Umhei mat; $\mathrm{d}$ - chemical composition

of sulphates (Kalashnikov et al., 2010). In microscopic studies, pyrite framboids were found inside the microbial mats or on its surface. Fig. 9 illustrates that pyrite framboids "grow" on the surface of diatom shell debris or occur separately as individual crystallites.

\section{Discussion}

Microorganisms are known to facilitate calcite precipitation (Wei et al., 2015). The conditions determining calcium carbonate formation are the presence of cyanobacteria, which can increase the $\mathrm{pH}$ of the environment, and a sufficient amount of $\mathrm{Ca}^{2+}$ ions. It was established that the amount of calcium in the microbial communities of the Baikal rift zone depends on the formation of calcite in microbial mats, which occurs when the concentration of calcium exceeds $10 \mathrm{mg} / \mathrm{L}$ (Lazareva et al., 2010). The water from
Umhei and Seyuyskiy springs contained no more than $8 \mathrm{mg} / \mathrm{L}, \mathrm{Ca}^{2+}$, whereas the water from Garga and Alla contained 23 and $31 \mathrm{mg} / \mathrm{L}$, respectively. Calcium carbonate precipitation can be accounted for by the increased influx of mineralised water and the abrupt change of $\mathrm{pH}$ in the photosynthesis zone due to the removal of $\mathrm{CO}_{2}$ in shallow waters, where water exchange is slow, and fast utilization of dissolved bicarbonate upsets the equilibrium. The most favourable conditions for this process are under the layer of actively growing cyanobacteria caused by the emerging local high $\mathrm{pH}$ zones and the influx of solution carrying $\mathrm{Ca}^{2+}$ and $\mathrm{CO}_{3}{ }^{-}$from below (Namsaraev et al., 2011). In this way, the metabolic activity of microorganisms creates microenvironments where calcite precipitation occurs.

A microbial community may serve as a

substrate for physicochemical carbonate 

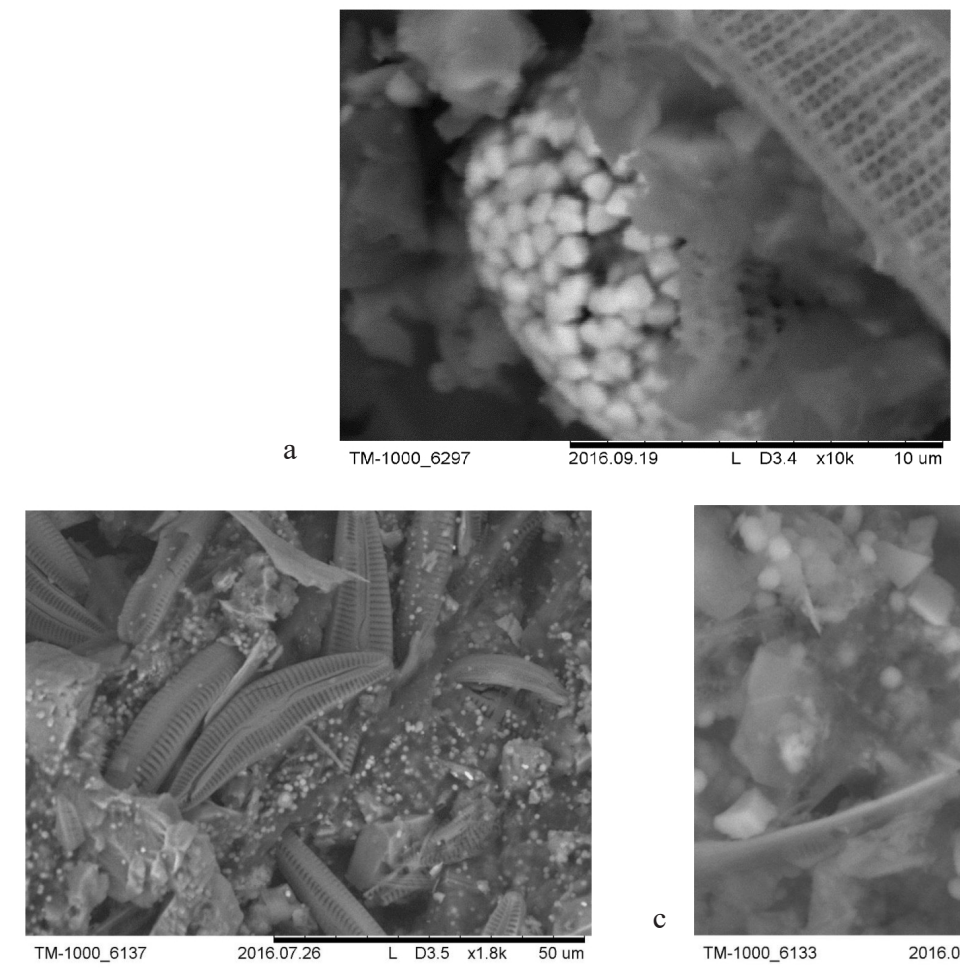

c

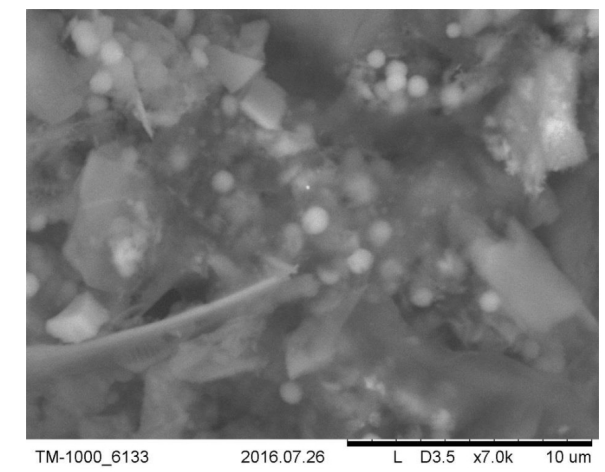

Fig. 9. Pyrite deposits in examined springs: Photo: scanning microscope, scale bars $=10-50 \mu \mathrm{m}$ $\mathrm{a}$ - pyrite framboid in the spring Kuchiger; b, $\mathrm{c}$ - deposits of individual pyrite crystallites, Umhei

precipitation, which is why it can have a crucial effect on the mineral product. In this case, precipitating particles adhere to a microbial mat or biofilm, exocellular polymers continually absorb $\mathrm{Ca}^{2+}$ ions, and carbonate crystals form on the surface of the biofilm, resulting in calcification.

The initial precipitation of calcium carbonate in microbial mats can be described as occurring in the following stages: 1) a local increase in alkalinity and the formation of the foci of supersaturation in the microdomains of the exopolysaccharide (EPS) matrix; 2) the formation of amorphous calcite gel; 3) the formation of nanospheres from a mixture of amorphous calcite and acid macromolecules of EPS; and 4) carbonate crystallisation around these nanospheres as nucleation centres (Zavarzin, 2002).

Silicates and aluminosilicates are the most widely distributed classes of minerals in nature, accounting for approximately $75 \%$ of the mass of the Earth's crust. Many silicates are the rockforming minerals of magmatic and metamorphic rocks. The presence of high-temperature silicates (kyanite, albite, anorthite and orthoclase) in a microbial community is apparently associated with their ingress from geological depositions in the location of springs. They are formed as a result of the metamorphism of sedimentary strata saturated with alumina when they are exposed to high temperature, high pressure and various gas and water solutions. This illustrates the role of the microbial community in the deposits of the silicon oxides quartz and opal.

Silicic acid in solution exists in the form of dissociated and molecular orthosilicic acid and $\mathrm{SiO}_{2}$ molecules; this form depends on the $\mathrm{pH}$ value, silica concentration, and the ratio of the alkali metal and silicon. Silicic acid comes from 
silicates, primarily feldspars; their solubility and dissociation into orthosilicic acid ions increases with increasing temperature and $\mathrm{pH}>9$ (Borisenko, Zamana, 1978).

In the hot water of thermal springs, the stability of silicates decreases, which contributes to the increase in the solubility of silica. With the gradual cooling of outflowing water and the decrease in the $\mathrm{pH}$, the excess silicic acid remains suspended in the form of a colloid and generally does not precipitate. Therefore, precipitation of silica occurs during the evaporation and cooling of the solution (Namsaraev et al., 2007). In the dried areas along the thermal stream bed, layered mucous films of cyanobacteria are formed that are partially or completely mineralised to form opal.

Initially, opal begins to precipitate in the form of islands with a diameter of 0.1-3 $\mu \mathrm{m}$. Then, the islands merge and form thin opal crusts that then thicken and replace the cell walls. The death of cells and the beginning of lysis aid in the penetration of silica into the cells and leads to their complete silicification. During rapid silicification, microfossils fully retain their volume and are not subject to further diagenetic changes. Inputs of new portions of silica trigger chemogenic precipitation of opal globules both outside and inside the cyanobacterial filaments and in the spaces between them. As a result, solid silica (geyserite) is formed (Astafieva et al., 2011).

Nevertheless, the role of the microbial community in the formation of silicate minerals remains largely unclear. It is believed that microbial fouling and mats function as nucleation centres for the formation of silicate minerals, and then an autocatalytic process of mineral formation occurs (Inagaki et al., 2003). Recent studies have shown that the role of the microbial community in the formation of geyserites can be more considerable than previously thought. A culture of Thermus sp. precipitated silica during the exponential growth phase, and the cells simultaneously synthesised a protein (Sip-silica-induced protein) that appeared only in the presence of colloidal silicon. The function of this protein is still unknown. It was suggested that silicon deposition is necessary to anchor cells on the surface of the substrate in a water flow (Inagaki et al., 2003).

Previously, laboratory studies showed that aqueous silica is heterogeneously deposited on organic surfaces by hydrogen bonding or by sorption of negatively charged silicon ions by positively charged functional groups (Urrutia, Beveridge, 1993). In contrast, the experimental results of Heaney and Yates (1998) showed that in saturated solutions, amorphous silica precipitated homogeneously and occurred as a polymer/ colloidal fraction of silicon dioxide deposited on organic surfaces. Similarly, Walter et al. (1972) suggested that precipitation of silica in hot springs is an inorganic process controlled by rapid cooling and evaporation of water after exiting the well and is independent of microorganisms.

Previous studies have also shown that the association of silicate minerals and bacterial surfaces is not caused by the direct interactions of silicon and bacteria. The results show that in supersaturated silicon dioxide solutions, microorganisms act as passive surfaces, and bacterial silicification is largely controlled by inorganic processes. It is shown that silicates are intensively formed in close contact with microorganisms in the environments of hot springs. Although microbial surfaces do not directly form silicon dioxide, they can play an important role in the aggregation of polymeric silicon dioxide and the precipitation of silica colloids (Yee et al., 2003). Silicon dioxide is formed as a result of a two-step reaction. First, silicic acid is formed by hydrolysis followed by condensation of tetramethyl orthosilicate $\mathrm{Si}$ $(\mathrm{OMe})_{4}\left(\mathrm{Me}=\mathrm{CH}_{3}\right)$. 
These processes occur due to both the mechanisms of active sorption and the accumulation of silicon dioxide on the surface of the cell wall, which can be concluded from the presence of bacterial cells with a dense multilayer capsule and cells having a cover from nanomineral particles. Biomineralisation occurs in water with a neutral $\mathrm{pH}$ and an ambient temperature. In some cases, bacterial exopolysaccharides can serve as a matrix for the nucleation of aluminosilicate minerals (Ueshima, Tazaki, 2001). The concentration of silica dissolved in seawater (a few $\mathrm{mg} / \mathrm{L}$ ) is too low for condensation. In the case of diatom algae, silica forms within "silicon sedimentary vesicles", where its content is controlled by proteins and polysaccharides (Yee et al., 2003). The degree of cyanobacterial silicification was determined by the concentration of silicon in the solution and the duration of the incubation. At the same time, the concentration of silicon is a more important mineralisation factor than the exposure time. Cyanobacteria are able to take an active part in precipitating silicon from solution by forming a thick glycocalyx that adsorbs silicon from the medium (Astafieva et al., 2011). Microorganisms act as reaction surfaces for the nucleation of heterogeneous silicon particles. Depending on the initial silica concentration, either porous precipitates, including a mixture of silicified and unmineralised cells, or precipitates having a denser structure with cells fossilised under a dense crust of silica were formed (Orange et al., 2013).

In the springs of Umhei and Kuchiger, precipitation of iron sulphide (pyrite) was observed. The presence of hydrogen sulphide (up to $31 \mathrm{mg} / \mathrm{L}$ ) in the springs was caused, among other factors, by the activity of sulphatereducing bacteria that restore sulphates using organic matter as an energy material. In natural environments, pyrite is often formed at the sites of organic decomposition resulting from bacterial sulphate reduction (Astafieva et al., 2005). Such pyrite framboids appear on Earth in the case of transformation of organic matter under anoxic conditions in the presence of sulfate-reducing bacteria. The claim of the biogenic origin of pyrite framboids is supported by their presence in living algobacterial mats in the hot springs on Kunashir Island (Fedorova et al., 1988).

\section{Conclusion}

The study of minerals of microbial mats in thermal springs of the Baikal rift zone showed that the microbial community in these springs participates in the formation of calcite, amorphous silica and opal. The formation of siliceous deposits can occur both extracellularly and intracellularly, which indicates that silicification can not only be bioinduced but also be biocontrolled (Gerasimenko et al., 2011). Cyanobacteria directly participate in the precipitation of calcite by creating microzones with a high $\mathrm{pH}$ and in the formation of a glycocalyx, which absorbs $\mathrm{Ca}^{2+}$ ions. Bacterial exopolysaccharides can serve as a matrix for the nucleation of silicon from a solution. Deposits of iron sulphide (pyrite framboids) formed as a result of the metabolic activity of microorganisms are found in hydrogen sulphide springs.

\section{Acknowledgement}

The authors are grateful to the staff of the Oxide Systems Laboratory of the Baikal Institute of Nature Management of the SB RAS for conducting XRD and decoding the diffractograms. Research was carried out with the support of the Project "Microbial communities of extreme natural systems: biological and functional diversity, biotechnological potential" No. 03372016-0004, State orders of FASO Russia No. of state registration AAAA-A17-117011810034-9, with partial support of RFBR No. 18-34-00552 mol_a. 


\section{References}

Astafieva M.M., Gerasimenko L.M., Geptner A.R., Zhegallo E.A., Zhmur S.I., Karpov G.A., Orleansky V.K., Ponomarenko A.G., Rozanov A.Yu., Sumina E.L., Ushatinskaya G.T. (2011) Fossil bacteria and other microorganisms in terrestrial rocks and astromaterials. Moscow, PIN RAS, $172 \mathrm{p}$. (in Russian)

Astafieva M.M., Rozanov A.Yu., Hoover R. (2005) Framboids: their structure and origin. Paleontological Journal, 39(5): 457-464

Borisenko I.M., Zamana L.V. (1978) Mineral waters of Buryat ASSR. Ulan-Ude, Buryat Publishing House, 162 p. (in Russian)

Canaveras J.C., Sacchez-Moral S., Soler V. (2001) Microorganisms and microbially induced fabrics cave walls. Geomicrobiology Journal, 18: 223-240

Chen L., Shen Y.H., Xie A.J., Huang B., Ji R., Guo R.Y., Tang W.Z. (2009) Bacteria-mediated synthesis of metal carbonate minerals with unusual morphologies and structures. Crystal Growth \& Design, 9: 743-754

Chou C.-W., Seagren E.A., Aydilek A.H., Lai M. (2011) Biocalcification of sand through ureolysis. Journal of Geotechnical and Geoenvironmental Engineering, 137 (12): 1179-1189

DeJong J.T., Mortensen B.M., Martinez B.C., Nelson D.C. (2010) Bio-mediated soil improvement. Ecological Engineering, 36: 197-210

De Muynck W., De Belie N., Verstraete W. (2010) Microbial carbonate precipitation in construction materials: a review. Ecological Engineering, 36: 118-136

Dupraz C., Reid R.P., Braissant O., Decho A.W., Norman R.C., Visscher P.T. (2009) Processes of carbonate precipitation in modern microbial mats. Earth-Science Reviews, 96: 141-162

Dupraz C., Visscher P.T. (2005) Microbial lithification in marine stromatolites and hypersaline mats. Trends in Microbiology, 13: 429-438

Fedorova T.A., Gerasimenko L.M., Bochko R.A., Zavarzin G.A. (1988) Micromineral secretions in thermophilic cyanobacterial communities. Journal of Volcanology and Seismology [Vulkanologiya i sejsmologiya], 1: 101-104 (in Russian)

Franke R.B., Bazylinski D.A. (2003) Biologically induced mineralization by bacteria. Reviews in Mineralogy and Geochemistry, 54: 95-114

Gerasimenko L.M., Orleansky V.K., Ushatinskaya G.T. (2011) On the sequence of precipitation of phosphates, carbonates and silica in the presence of bacteria under natural conditions and in an experiment. Mineralogical prospects. Syktyvkar, Geoprint, p. 37-38 (in Russian)

Hammes F., Boon N., de Villiers J., Verstraete W., Siciliano S.D. (2003) Strain-specific ureolytic microbial calcium carbonate precipitation. Applied and Environmental Microbiology, 69: 4901-4909

Heaney P.J., Yates D.M. (1998) Solution chemistry of wood silicification. Geological society of America annual meeting, Abstracts Programm, 30, A-3

Inagaki F., Motomura Y., Ogata S. (2003) Microbial silica deposition in geothermal hot waters. Applied Microbiology and Biotechnology, 60: 605-611

Jha B.K., Pragash M.G., Cletus J. (2009) Simultaneous phosphate solubilization potential and antifungal activity of new fluorescent pseudomonad strains, Pseudomonas aeruginosa, P. plecoglossicida and P. mosselii. World Journal of Microbiology and Biotechnology, 25: 573-581 
Kalashnikov A.M., Tudupov A.V., Zaitseva S.V., Barkhutova D.D., Namsaraev B.B. (2010) A diversity of sulfate-reducing bacteria in the alkaline springs of Baikal region. The Buryat State University Bulletin [Vestnik Buryatskogo gosuniversiteta], 4: 93-95 (in Russian)

Konhauser K.O., Phoenix V.R., Adams D.G., Bottrell S.H., Head I.M. (2001) Microbial-silica interactions in modern hot spring sinter: possible analogues for Precambrian siliceous stromatolites. Sedimentology, 48: 415-433

Lazareva E.V., Bryanskaya A.V., Zhmodik S.M., Smirnov S.Z., Pestunova O.P., Barkhutova D.D., Polyakova E.V. (2010) Mineral formation in cyanobacterial mats of the Barguzin basin alkaline hot springs (Baikal Rift Zone). Doklady Earth Sciences, 430(2): 218-222

McConnaughey T.A., Whelan F.F. (1997) Calcifiation generates protons for nutrient and bicarbonate uptake. Earth-Science Reviews, 42: 95-117

Namsaraev B.B., Barkhutova D.D., Danilova E.V. (2011) Geochemical activity of microorganisms of Baikal rift zone hydrotherms. Novosibirsk, Geo, 302 p. (in Russian)

Namsaraev Z.B., Gorlenko V.M., Namsaraev B.B., Barkhutova D.D. (2006) Microbial community of alkaline hydrotherms. Novosibirsk, SB RAS, 111 p. (in Russian)

Namsaraev B.B., Khahinov V.V., Garmaev E.Zh., Barkhutova D.D., Namsaraev Z.B., Plusnin A.M. (2007) Aquatic systems of Barguzin basin. Ulan-Ude, Buryat State University, 154 p. (in Russian)

Noffke N., Eriksson K.A., Hazen R.M., Simpson E.L. (2006) A new window into Early Archean life: Microbial mats in Earth's oldest siliciclastic tidal deposits (3.2 Ga Moodies Group, South Africa). Geology, 34: 253-256

Orange F., Lalonde S.V., Konhauser K.O. (2013) Experimental simulation of evaporationdriven silica sinter formation and microbial silicification in hot spring systems. Astrobiology, 13(2): $163-176$

Perry C.C., Keeling-Tucker T. (2000) Biosilicification: the role of the organic matrix in structure control. Journal of Biological Inorganic Chemistry, 5: 537-550

Phoenix V., Konhauser K., Howe A. (2000) Mechanisms of rapid silicate biomineralisation in hot springs. Journal of Conference Abstracts, 5 (2): 794

Rodriguez-Navarro C., Jroundi F., Schiro M. (2012) Influence of substrate mineralogy on bacterial mineralization of calcium carbonate: implication for stone conservation. Applied and Environmental Microbiology, 78: 4017-4029

Shargaeva O.V., Kalashnikov A.M., Tsyrenova D.D. (2013) The content of chlorophyll $a$ and the diversity of cyanobacteria in microbial mats of the Buryatia hydrotherm. The Buryat State University Bulletin [Vestnik Buryatskogo gosuniversiteta], 4: 158-161 (in Russian)

Skinner H.C.W. (2005) Biominerals. Mineralogical Magazine, 69 (5): 621-641

Tice M.M., Lowe D.R. (2004) Photosynthesis microbial mats in the 3.416-Myr-old ocean. Nature, 431: $549-552$

Ueshima M., Tazaki K. (2001) Possible role of microbial polysaccharides in nonthronite formation. Clays and Clay Minerals, 49 (4): 292-299

Urrutia M.M., Beveridge T.J. (1993) Mechanism of silicate binding to the bacterial cell wall in Bacillus subtilis. Journal of Bacteriology, 175: 1936-1945

Walter M.R., Bauld J., Brock T.D. (1972) Siliceous algal and bacterial stromatolites in hot spring and geyser effluents of Yellowstone National Park. Science, 178: 402-405 
Warthmann R., Van Lith Y., Vasconcelos C. (2000) Bacterially induced dolomite precipitation in anoxic culture experiments. Geology, 28: 1091-1094

Wei S., Cui H., Jiang Z., Liu H., He H., Fang N. (2015) Biomineralization processes of calcite induced by bacteria isolated from marine sediments. Brazilian Journal of Microbiology, 46 (2): 455464

Weiner S., Dove P.M. (2003) An overview of biomineralization and the problem of the vital effect. Reviews in Mineralogy and Geochemistry, 54: 1-31

Wen Z.F., Zhong J.H., Li Y., Guo Z.Q., Gao J.B., Xu X.L. (2004) Current study on genesis and formation conditions of stromatolites. Geological Journal China University, 10(3): 418-428

Yee N., Phoenix V.R., Konhauser K.O., Benning L.G., Ferris F.G. (2003) The effect of cyanobacteria on silica precipitation at neutral $\mathrm{pH}$ : Implications for bacterial silicification in geothermal hot springs. Chemical Geology, 199: 83-90

Zavarzin G.A. (2002) Microbial geochemical calcium cycle. Microbiology, 71 (1): 1-17 